\title{
Pengembangan alat sterilisasi mikroorganisme dan pelaksanaan disinfeksi berkala sebagai upaya untuk memutus rantai penularan covid-19
}

\author{
Irham Fadlika ${ }^{1 *}$, Aripriharta ${ }^{2}$, Irawan Dwi Wahyono ${ }^{3}$, Muhammad Rizal \\ Andriansyah $^{4}$, M. Ricko Gunawan ${ }^{5}$, Eka Mistakim ${ }^{6}$, Ach. Syahrudin \\ Fakhri $^{7}$
}

\footnotetext{
${ }^{1}$ Universitas Negeri Malang, Indonesia, email: irham.fadlika.ft@um.ac.id

${ }^{2}$ Universitas Negeri Malang, Indonesia, email: aripriharta.ft@um.ac.id

${ }^{3}$ Universitas Negeri Malang, Indonesia, email: irawan.dwi.ft@um.ac.id

${ }^{4}$ Universitas Negeri Malang, Indonesia, email: m.rizal.andriansyah@um.ac.id

${ }^{5}$ Universitas Negeri Malang, Indonesia, email: rickomuhamad111@gmail.com

6Universitas Negeri Malang, Indonesia, email: ekamistakim15@gmail.com

7Universitas Negeri Malang, Indonesia, email: as2f0105@gmail.com

*Koresponden penulis
}

\section{Info Artikel}

Diajukan: 05 Mei 2021

Diterima: 24 Sept 2021

Diterbitkan: 09 Okt 2021

Keywords:

sprayer; covid-19;

disinfectant; solar power

Kata Kunci:

alat penyemprot; covid-19;

disinfektan; tenaga surya

Lisensi:

cc-by-sa

\begin{abstract}
Covid-19 is a malignant virus that has spread throughout the world, including Indonesia. In Indonesia alone, Covid-19 has proliferated to 502 districts and cities in 34 provinces, including Harjokuncaran Village, Sumbermanjing Wetan District, Malang Regency. Two main issues, community economy problem and inadequacy of health facilities to fight Covid-19, are addressed and mitigated in this work. We offer some solutions, including the production of a disinfectant sprayer and a call to carry out sterilization activities in public places together. The realization of this community service program uses the Dignan method which includes five stages. The initial implementation of this activity, which was carried out on October 5, 2020 has gone smoothly with the help of the community, while the tools that have been fully provided to the residents are used to carry out sterilization activities on a regular basis. Six months after the activity, we evaluated the success of this endeavor. There are three indicators of success in this activity, namely a recapitulation of monthly spraying activities from October 2020 - March 2021, the addition of positive cases of Covid19 , and how much knowledge of residents about the importance of spraying disinfectant activities.
\end{abstract}

\section{Abstrak}

Covid-19 merupakan virus berbahaya yang telah menyebar ke seluruh dunia, termasuk Indonesia. Di Indonesia sendiri, Covid-19 telah merebak ke 502 kabupaten dan kota di 34 provinsi, termasuk Desa Harjokuncaran Kecamatan Sumbermanjing Wetan Kabupaten Malang. Terdapat dua permasalahan utama yang diangkat dan dimitigasi terkait penanganan Covid-19 di Desa Harjokuncaran ini, yaitu perekonomian masyarakat dan fasilitas kesehatan yang kurang memadai. Solusi yang ditawarkan yaitu pembuatan alat penyemprot disinfektan dan seruan untuk melakukan kegiatan sterilisasi tempat umum secara bersama-sama. Realiasasi program pengabdian ini menggunakan metode Dignan yang mencakup lima tahapan. Pelaksanaan awal kegiatan ini dilaksanakan pada tanggal 5 Oktober 
2020 telah berjalan lancar dengan dibantu warga desa, sedangkan alat yang telah diberikan sepenuhnya kepada warga dipergunakan untuk melakukan kegiatan sterilisasi secara berkala. Enam bulan pasca kegiatan, tim pengabdian melakukan evaluasi terhadap keberhasilan kegiatan ini. Ada tiga indikator keberhasilan dalam kegiatan ini yaitu rekapitulasi kegiatan penyemprotan perbulan dari Oktober 2020 - Maret 2021, penambahan kasus positif Covid-19, dan seberapa besar pengetahuan warga tentang pentingnya kegiatan penyemprotan disinfektan.

\section{PENDAHULUAN}

Corona Virus Disease 2019 (Covid-19) merupakan penyakit menular yang disebabkan oleh jenis coronavirus yaitu SARS-CoV-2 (Guan et al., 2020). Virus ini memiliki selubung lipid luar yang rapuh, sehingga membuat virus ini mudah mati terhadap cairan disinfektan dan alkohol (WHO, 2020). Meskipun begitu, virus ini dapat bertahan sampai berhari-hari pada media tertentu. Pada sebuah penelitian menjelaskan bahwa Covid-19 dapat bertahan 4 jam pada tembaga, 24 jam pada kain, kayu, dan kardus, 2 hari pada kaca, hingga 4 hari pada stainless steel dan plastik (Aboubakr et al., 2020; Corpet, 2021; Dehbandi \& Zazouli, 2020; Kwon et al., 2020; van Doremalen et al., 2020).

Covid-19 termasuk penyakit yang menyerang sistem pernapasan dan dapat menular umumnya melalui droplets atau tetesan cairan yang berasal dari batuk dan bersin yang tak terlihat yang dilepaskan ke udara dari orang yang terinfeksi (Li et al., 2020; Morawska et al., 2020; Peretto et al., 2020; Shim et al., 2020). Karena sifatnya yang mudah menyebar, Covid-19 dengan cepat menyebar luas ke berbagai negara. Kasus pertama kali terkonfirmasi di Wuhan pada tangal 31 Desember 2019 (Sohrabi et al., 2020). Di Indonesia kasus positif pertama kali terkonfirmasi pada tanggal 2 Maret 2020 yang kemudian menyebar ke 34 provinsi dan tercatat per 9 April 2021 data dari kasus terkonfirmasi positif di Indonesia mencapai 1.552.880 (KPCPEN, 2021). Wilayah yang terdampak mencakup 502 kabupaten dan kota di 34 provinsi termasuk Kabupaten Malang dimana, di Kabupaten Malang tercatat pada tanggal 9 April 2021 kasus positif 2819, sembuh 2625 dan meninggal 175 (Dinkes Kab. Malang, 2021). Berikut ini peta persebaran Covid-19 di Kabupaten Malang dapat dilihat pada Gambar 1.

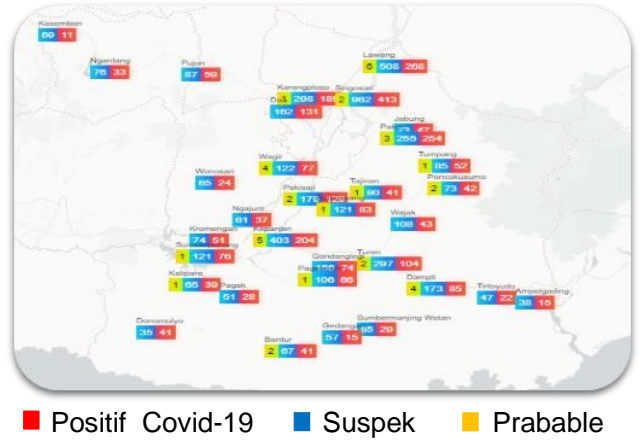

Gambar 1. Peta Persebaran Covid-19 di Kabupaten Malang per April 2021

Sumber: SATGAS Covid-19. KAB. MALANG (malangkab.go.id) 
Penyebaran Covid-19 di Kabupaten Malang terus bertambah akibat dari penanganan yang kurang tepat termasuk di Desa Harjokuncaran Kecamatan Sumbermanjing Wetan. Secara umum, masyarakat pedesaan merupakan kategori yang rentan dalam kondisi pandemi Covid-19 dimana mayoritas penduduknya tidak dapat secara langsung mendapatkan akses terhadap fasilitas kesehatan yang memadai ketika terjangkit virus dan dari sisi ekonomi, mereka lebih mengutamakan mendapatkan pendapatan untuk memenuhi kebutuhan sehari-hari (Olivia et al., 2020; Phillipson et al., 2020; Ranscombe, 2020; Suryahadi et al., 2020). Hal tersebut yang kami temukan menjadi permasalahan utama dalam penanganan Covid-19 di Desa Harjokuncaran. Dengan semakin bertambahnya kasus positif, masyarakat desa tersebut juga minim kesadaran untuk menerapkan protokol kesehatan.

Penerapan anjuran kerja dari rumah (work from home) untuk membatasi kegiatan sulit untuk dilaksanakan di Desa Harjokuncaran karena mayoritas warga berprofesi sebagai petani, pedagang toko dan berjualan di pasar. Urgensi ini yang menyebabkan interaksi antar warga tetap terjadi dengan sering mengabaikan anjuran untuk menjaga jarak. Selain itu, tingkat pemahahaman dan kesadaran masyarakat untuk mematuhi peraturan memakai masker dan mencuci tangan setelah berkegiatan juga tidak sempurna lantaran sedikitnya sosialisasi dan fasilitas untuk mencegah penularan Covid-19 seperti tempat cuci tangan, hand sanitizer, dan alat penyemprot disinfektan di ruang-ruang publik seperti jalan raya, masjid, sekolah, balai desa, dan pasar yang merupakan tempat paling rawan untuk menularkan Covid-19.

Berdasarkan permasalahan yang telah dipaparkan, terdapat dua solusi yang dilakukan dalam kegiatan pengabdian ini. Pertama, melakukan pembuatan dan pengembangan pada alat semprot disinfektan yang ekonomis dan praktis. Terdapat dua buah alat yang diwujudkan dalam aktivitas ini yaitu alat semprot yang dapat menjangkau tempat yang luas dan alat semprot yang dapat menjangkau tempat yang lebih khusus. Alat semprot yang dapat menjangkau tempat lebih luas memiliki kapasitas 1000 liter dan digunakan untuk penyemprotan di jalan umum dan bagian depan dari tempat-tempat umum, sedangkan alat semprot yang menjangkau area lebih khusus memiliki kapasitas 25 liter dan digunakan untuk menyemprot bagian yang sulit dijangkau seperti bagian dalam masjid, sekolah, perumahan padat dan pasar. Kedua instrumen ini bertujuan untuk sterilisasi mikroorganisme khususnya Covid-19 demi mewujudkan masyarakat yang sehat dan sadar akan kebersihan lingkungan.

Kedua, sosialisasi pentingnya menjaga kebersihan diri sendiri maupun lingkungan secara disipin. Beberapa langkah yang dapat dilakukan yaitu mencuci tangan, menggunakan masker, menjaga daya tahan tubuh, menerapkan physical distancing, membersihkan rumah dan melakukan disinfeksi pada peralatan rumah tangga maupun lingkungan (Nugrahaeni \& Permanasari, 2021). Disinfeksi atau penyemprotan disinfektan yang dilakukan secara berkala menjadi sebuah solusi yang tepat dalam mencegah atau memutus penularan Covid-19 (Nur \& Baru, 2021). Pada pengabdian ini, masyarakat dihimbau dan dilibatkan untuk melakukan kegiatan penyemprotan 
disinfektan secara kolektif ke beberapa tempat yang biasa digunakan untuk berkumpul seperti jalan raya, masjid, sekolah, balai desa, dan pasar.

Bab-bab selanjutnya akan membahas metode kegiatan yang diusulkan beserta tahapannya, analisis dari hasil yang telah dicapai pada saat dan pasca kegiatan pengabdian berdasarkan indikator keberhasilan program, dan kesimpulan dari kegiatan ini.

\section{METODE PELAKSANAAN}

Pelaksanaan kegiatan pengabdian ini bertujuan untuk mencegah penularan Covid-19 di Desa Harjokuncaran dan didesain dengan mengacu pada teori Dignan. Teori ini dilakukan dengan menentukan sasaran pada mitra dengan mengembangkan suatu program sehingga program tersebut dapat terlaksana sesuai dengan harapan. Menurut Dignan \& Carr (1992) berikut ini tahapan-tahapan program yang dilaksanakan: analisis masalah (community analysis), penilaian target (targeted assessment), pengembangan program (program plan development), implementasi (implementation), dan evaluasi (evaluation) seperti ditunjukkan pada Gambar 2.

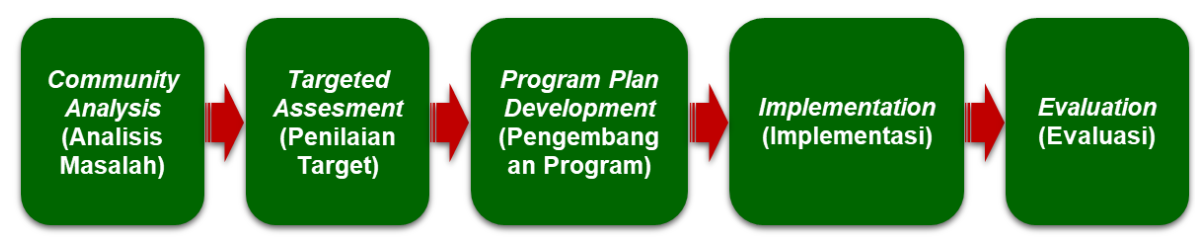

Gambar 2. Diagram Alir Pelaksanaan Program Pengabdian

Dari penjabaran teori Dignan diatas, maka pelaksanaan program pengabdian ini dapat dikembangkan dan disusun menjadi diagram alir yang ditunjukan pada Gambar 2. Berikut penjelasan tahapan-tahapan yang terdapat pada diagram alir:

Pada tahap pertama diawali dengan analisis masalah. Analisis masalah dilaksanakan dengan survei lokasi ke Desa Harjokuncaran Kecamatan Sumbermanjing Wetan Kabupaten Malang, dengan tujuan mengetahui secara detail permasalahan yang dihadapi warga. Diperlukan koordinasi dengan kepala desa dan warga setempat, untuk mengetahui keadaan masyarakat dan lingkungan Desa Harjokuncaran. Dari hasil koordinasi dan survei lapangan, maka dapat ditentukan permasalahan yang terjadi untuk selanjutnya ditentukan solusi yang tepat. Pada tahap kedua dilakukan penilaian target. Pada tahap ini dilakukan pengkajian untuk menentukan solusi yang tepat dalam mengatasi permasalahan yang ada di Desa Harjokuncaran. Solusi tersebut dijabarkan kedalam suatu program, program inilah yang diharapkan akan menyelesaikan permasalahan. Pada tahap ketiga yaitu pengembangan program. Agar solusi yang dibuat dapat memberikan hasil yang maksimal, maka dari solusi-solusi tersebut dibuat menjadi program terstruktur yang dilaksanakan oleh tim pengabdian dan warga desa Harjokuncaran. Pada tahap keempat yaitu implementasi pelaksanaan. Pada tahap ini, program yang telah dibentuk dan dijadwalkan dilaksanakan sesuai dengan perencanaan. Pelaksanaan kegiatan 
dilakukan bersama dengan warga desa Harjokuncaran dengan tetap mematuhi protokol kesehatan. Pada tahap kelima yaitu evaluasi. Setelah kegiatan ini berakhir, proses evaluasi akan dilaksanakan dengan pengkajian ulang mengenai keadaan di lingkungan Desa Harjokuncaran untuk mengetahui tingkat keberhasilan program yang dilakukan untuk selanjutnya ditarik kesimpulan.

\section{HASIL DAN PEMBAHASAN}

Dengan mengikuti alur dari metode Dignan, maka dilakukan tahapantahapan yang dilakukan mulai dari tahap analisis masalah hingga tahap evaluasi. Tahapan-tahapan tersebut dilakukan oleh tim pengabdi yang bekerja sama dengan pihak mitra yaitu warga desa Harjokuncaran guna untuk mengetahui permasalahan yang ada di Desa Harjokuncaran serta menyelesaikan permasalahannya. Berikut ini hasil dan pembahasan dari pelaksanaan program pengabdian di Desa Harjokuncaran.

\section{Analisis Masalah (community analysis)}

Mewabahnya Covid-19 menyebabkan permasalahan di Desa Harjokuncaran. Melalui analisis masalah pada metode Dignan untuk mengetahui secara detail permasalahan yang dihadapi warga desa Harjokuncaran maka dilakukan survei ke lokasi. Dari survei yang dilaksanakan dan berkomunikasi langsung dengan masyarakat desa Harjokuncaran, maka diketahui permasalahan yang ada. Berikut ini permasalahan yang ada di Desa Harjokuncaran: (a) Beberapa warga terjangkit Covid-19; (b) Minimnya penanganan untuk menekan penyebaran Covid-19; (c) Minimnya tindakan pencegahan berupa fasilitas kesehatan seperti tempat cuci tangan dan penyemprotan disinfektan pada lingkungan dan tempat-tempat umum; (d) Minimnya peralatan yang menunjang dalam pelaksanaan penyemprotan cairan disinfektan; (e) Minimnya kesadaran bersama untuk memutus rantai penularan Covid-19.

\section{Penilaian Target (targeted assessment)}

Untuk mengatasi permasalahan yang ada di Desa Harjokuncaran, maka dari hasil analisis permasalahan dapat ditentukan solusi yang relevan sesuai permasalahannya. Mengacu pada metode Dignan pada langkah penilaian target, maka ditentukan solusi berdasarkan permasalahan yang ada. Berikut ini solusi yang diberikan dalam program pengabdian ini: (a) Sosialisasi kegiatan tentang pentingnya menjaga kebersihan sendiri maupun lingkungan secara disiplin; (b) Pembuatan cairan disinfektan; (c) Penyemprotan cairan disinfektan dilingkungan Desa Harjokuncaran; (d) Pengadaan alat penyemprot disinfektan yang menunjang kegiatan penyemprotan secara berkala; (e) Inovasi alat penyemprot disinfektan berupa alat penyemprot bertenaga surya.

\section{Pengembangan Program (program plan and development)}

Untuk mewujudkan agar solusi dapat memberikan manfaat yang baik bagi masyarakat. Berikut ini penjabaran dari pengembangan program pengabdian ini untuk mewujudkan solusi yang diberikan: 
a. Sosialisasi

Sosialisasi dilakukan oleh tim pengabdian mengenai penyemprotan disinfektan dan pentingnya mematuhi protokol kesehatan untuk mencegah penularan Covid-19. Kegiatan sosialisasi berisikan mengenai pentingnya mencuci tangan, memakai masker, menjaga daya tahan tubuh, menerapkan physical distancing, membersihkan rumah dan melakukan disinfeksi pada peralatan rumah tangga. Kegiatan ini juga membahas mengenai perencanaan dan pelaksanaan kegiatan penyemprotan disinfektan bersama warga. Penentuan kegiatan dilakukan dengan musyawarah bersama warga desa Harjokuncaran. Hal ini dapat dilihat pada Gambar 3.

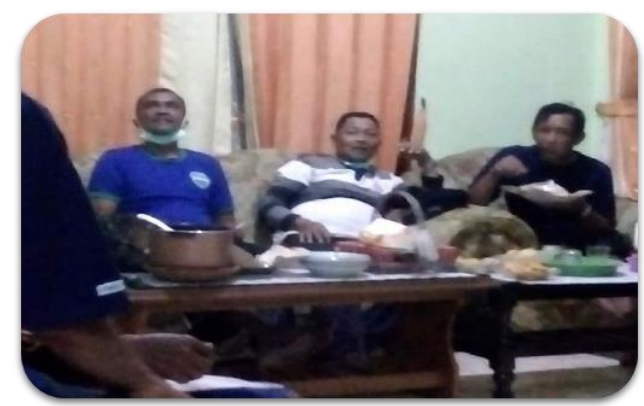

Gambar 3. Diskusi tim pengabdian dan warga Desa Harjokuncaran terkait penentuan waktu penyemprotan disinfektan

Hasil dari kegiatan musyawarah bersama warga desa Harjokuncaran diantaranya: (a) Pelaksanaan kegiatan penyemprotan cairan disinfektan dilaksanakan pada tanggal 5 Oktober 2020; (b) Kegiatan penyemprotan cairan disinfektan dilakukan 8 kali setiap bulan atau 2 kali setiap minggu; (c) Alat penyemprot cairan disinfektan bertenaga surya akan dihibahkan ke masyarakat dan digunakan sesuai kebutuhan; (d) Tempat-tempat yang akan dilakukan penyemprotan meliputi jalan dan fasilitas umum diantaranya yaitu jalan raya, masjid, sekolah, balai desa, dan pasar.

b. Pembuatan cairan disinfektan

Salah satu upaya untuk menjaga lingkungan tetap bersih, sehat, dan bebas dari paparan Covid-19 adalah dengan melakukan penyemprotan cairan disinfektan (Musafira et al., 2020). Bahan yang digunakan yaitu air bersih, cairan sodium hiploklorit dan pewangi (Larasati \& Haribowo, 2020). Sodium hiploklorit dipilih sebagai bahan pembuatan cairan disinfektan karena cairan ini memiliki sifat anti mikroba yang dapat membunuh bakteri maupun virus. Konsentrasi pembuatan cairan disinfektan yaitu setiap $20 \mathrm{ml}$ sodium hiploklorit ditambahkan pada $1000 \mathrm{ml}$ air bersih. Selain itu juga ditambahkan cairan pewangi secukupnya sebagai bahan campuran yang bertujuan untuk memberi aroma pada cairan disinfektan. 
c. Perancangan alat penyemprot disinfektan

Ada dua perangkat penyemprot yang dibuat dan dikembangkan dalam pengabdian ini yaitu alat penyemprot dengan bahan bakar bensin yang dapat menjangkau sasaran luas, serta alat penyemprot berbasis energi matahari. Untuk alat penyemprot disinfektan yang pertama dengan sasaran area luas dan memiliki daya tampung cairan disinfektan sebanyak 1000 liter dengan mesin penyemprot menggunakan mesin cuci kendaraan dengan bahan bakar bensin tipe NGL 5,5 HP Complate Power Sprayer Set. Inovasi dari mesin penyemprot ini terletak pada mesin yang digunakan berasal dari mesin yang awalnya digunakan sebagai penyemprot kendaraan diubah menjadi mesin untuk menyemprot cairan disinfektan. Inovasi alat penyemprot disinfektan dengan jangkauan luas ditampilkan pada Gambar 4.

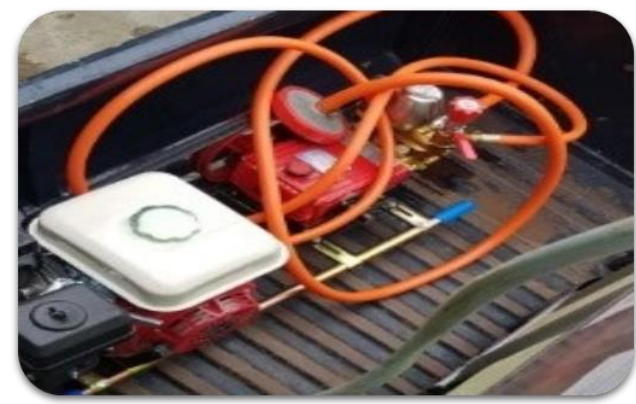

Gambar 4. Alat Penyemprot NGL 5,5 HP Complate Power Sprayer Set

Sebagai tambahan, inovasi dilakukan dengan melakukan pembuatan penyemprot berbasis energi matahari. Alat ini merupakan sebuah pengembangan dari alat penyemprot yang memanfaatkan sumber energi terbarukan yaitu tenaga surya. Sumber energi alat penyemprot ini memanfaatkan cahaya matahari yang di simpan pada baterai. Rancangan alat penyemprot bertenga surya dapat dilihat pada Gambar 5.

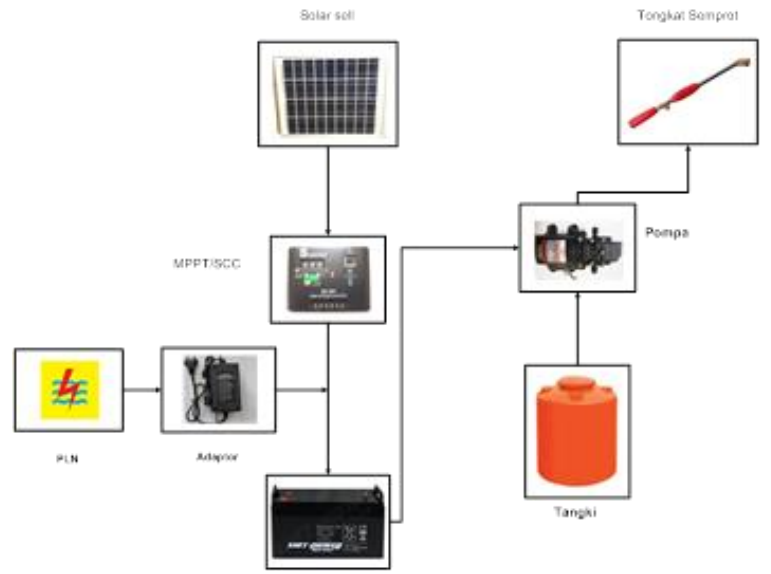

Gambar 5. Rangkaian Alat Penyemprot Bertenaga Surya 
Komponen utama dari alat penyemprot disinfektan bertenaga surya yaitu:

(1) Baterai yang digunakan yaitu baterai jenis deep cycle yang memiliki kapasitas 18Ah dengan tegangan 12V. Dengan kapasitas 18Ah alat penyemprot disinfektan bertenaga surya dapat digunakan 1-3 jam pemakaian

(2) SCC (Solar Charge Controller) berfungsi untuk pengatur tegangan yang dihasilkan oleh panel surya. SCC yang digunakan memiliki output $12 \mathrm{~V} 10 \mathrm{~A}$.

(3) Pompa air DC berfungsi untuk memompa air atau cairan disinfektan yang ada di dalam tangki. Pompa yang digunakan memiliki spesifikasi tegangan $12 \mathrm{~V}$ dan arus 2,6 A, tekanan $100 \mathrm{Psi}$, dan kecepatan penyaluran air 3,6 L/m.

(4) Panel Surya yang berfungsi untuk mengubah atau mengkonversi energi dari cahaya menjadi energi listrik. Panel Surya yang digunakan ini memiliki kapasitas daya maksimal $20 \mathrm{Wp}$, tegangan maksimal 17,8V dan arus maksimal 1,13A. Selain itu terdapat pula opsi pengisian dari listrik AC menggunakan adaptor.

d. Pembuatan alat penyemprot disinfektan bertenaga surya

Berikut proses pembuatan alat penyemprot cairan disinfektan bertenaga surya: (a) Pemotongan besi kerangka. Besi kerangka dari alat ini terbuat dari besi galvanis yang kokoh dan ringan; (b) Pengelasan besi galvanis bertujuan untuk menjadikan kerangka alat yang kokoh; (c) Pengecatan agar untuk melindungi alat dari korosi; (d) Perakitan kerangka dengan komponen pompa air DC, baterai, SCC, panel surya, tangki, tongkat semprot, komponen kelistrikan dan lainlain; (e) Pengujian alat. Pada proses pengujian alat, alat diuji sampai alat dapat berfungsi dengan baik dan siap untuk diserahkan.

e. Uji coba penyemprot disinfektan bertenaga surya

Untuk melihat tingkat kemampuan alat penyemprotan cairan disinfektan bertenaga surya ini, pengujian dengan menggunakan hambatan yang bervariasi dilakukan untuk mengetahui tekanan dan durasi kerja perangkat selama pemakaian.

Tabel 1. Hasil Pengujian alat penyemprot disinfektan bertenaga surya

\begin{tabular}{ccccccc}
\hline No. & $\begin{array}{c}\text { Variabel } \\
\text { Resistor } \\
(\mathbf{\Omega})\end{array}$ & $\begin{array}{c}\text { Tegangan } \\
\text { pompa air } \\
(\mathbf{V})\end{array}$ & $\begin{array}{c}\text { Arus } \\
\text { pompa air } \\
(\mathbf{I})\end{array}$ & $\begin{array}{c}\text { Tekanan } \\
\text { pompa air } \\
(\mathbf{P s i})\end{array}$ & $\begin{array}{c}\text { Durasi } \\
\text { Pemakaian } \\
(\text { Jam) }\end{array}$ & $\begin{array}{c}\text { Kualitas tekanan } \\
\text { air }\end{array}$ \\
\hline 1 & $0 \mathrm{k}$ & 12,58 & 2,49 & 85,1 & 5,8 & Optimal \\
2 & $1 \mathrm{k}$ & 11,29 & 2,21 & 77,6 & 6,51 & Optimal \\
3 & $2 \mathrm{k}$ & 10,1 & 1,89 & 68 & 7,6 & Optimal \\
4 & $3 \mathrm{k}$ & 8,76 & 1,6 & 59,3 & 9 & Kurang Optimal \\
5 & $4 \mathrm{k}$ & 7,48 & 1,37 & 51,1 & 10,51 & Kurang Optimal \\
6 & $5 \mathrm{k}$ & 6,2 & 1,12 & 43,1 & 12,8 & Kurang Optimal \\
7 & $6 \mathrm{k}$ & 4,97 & 0,91 & 34,4 & 15,8 & Tidak Optimal \\
8 & $7 \mathrm{k}$ & 3,66 & 0,59 & 25,7 & 24,4 & Tidak Optimal \\
9 & $8 \mathrm{k}$ & 2,39 & 0,43 & 17,1 & 33,52 & Tidak Optimal \\
10 & $9 \mathrm{k}$ & 1,17 & 0,2 & 8,9 & 72 & Tidak Optimal \\
11 & $10 \mathrm{k}$ & 0 & 0 & 0 & 0 & Tidak Optimal \\
\hline
\end{tabular}


Dokumentasi kegiatan pembuatan alat penyemprot cairan disinfektan bertenaga surya yang mencakup pemotongan besi galvanis untuk kerangka alat, perakitan komponen, penggabungan komponen dan box alat, dan penyelesaian akhir alat, masing-masing ditampilkan oleh Gambar 6-9. Tabel 1 menampilkan uji coba sederhana perangkat penyemprot disinfektan tenaga surya dengan kondisi panel surya dan baterai dalam kondisi standar (iradiasi matahari normal dan baterai dalam kondisi penuh). Pada kondisi tersebut, beberapa titik uji dilakukan dengan mengatur keluaran pompa menggunakan hambatan variabel $(0-10 \mathrm{k} \Omega)$, dan diperoleh dalam kondisi pengaturan untuk kecepatan maksimum $(0 \mathrm{k} \Omega)$, alat dapat bekerja kurang lebih selama durasi pemakaian efektif 5,8 jam. Data ini dapat dijadikan acuan lebih lanjut bagi masyarakat Desa Harjokuncaran untuk bijak menggunakan perangkat ini sesuai kebutuhan tekanan pompa disinfektan yang diperlukan berdasarkan kondisi baterai mapun cuaca yang tidak ideal.

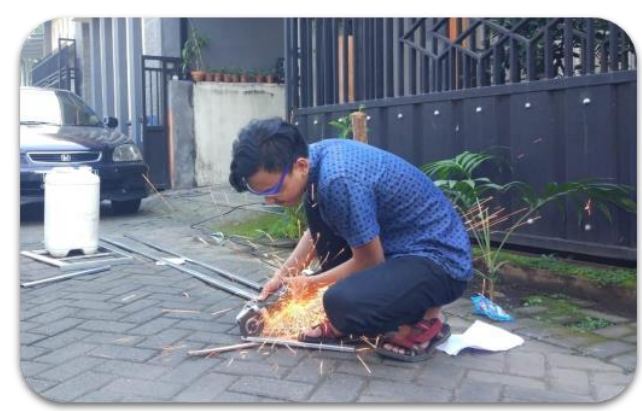

Gambar 6. Proses pemotongan besi galvanis

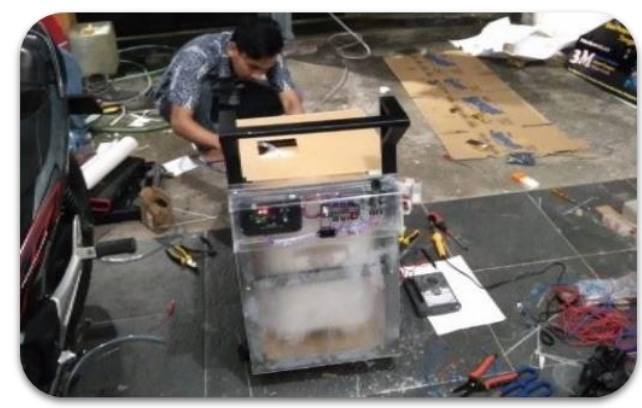

Gambar 7. Proses perakitan komponen 


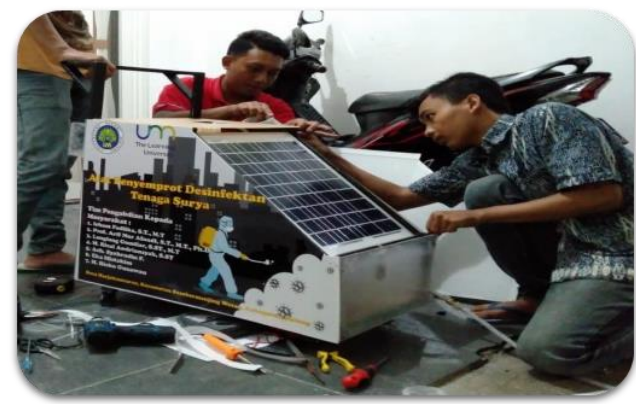

Gambar 8. Penggabungan komponen dan pemasangan box alat

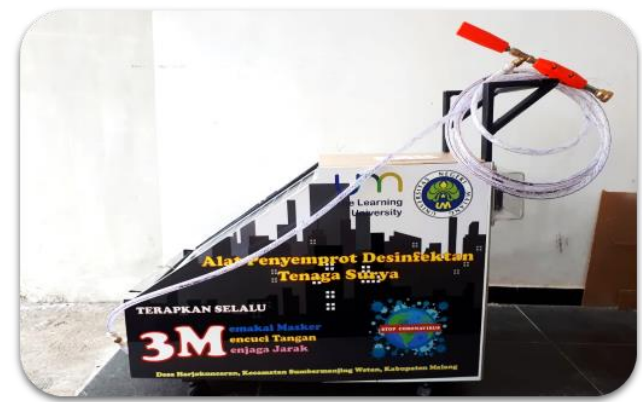

Gambar 9. Tampilan samping alat penyemprot disinfektan bertenaga surya

\section{Implementasi (implementation)}

Tahap keempat yaitu Implementasi. Tahap ini merupakan tahap pelaksanaan kegiatan, penentuan waktu kegiatan berdasarkan hasil musyawarah warga Desa Harjokuncaran. Kegiatan pelaksanaan dilaksanakan dalam beberapa langkah yaitu penyerahan alat pada warga Desa Harjokuncaran, persiapan alat, dan kegiatan penyemprotan bersama. Tahap persiapan alat meliputi persiapan mobil pengangkut, persiapan cairan disinfektan, air bersih, alat penyemprot, drum penampung cairan, dan sekaligus melakukan uji coba alat terakhir adalah penentuan sasaran penyemprotan cairan disinfektan.

Penyemprotan disinfektan mulai dilakukan sekitar pukul 19.00 WIB, tempat-tempat yang menjadi sasaran penyemprotan yaitu dua Rukun Tetangga (RT) yaitu RT 05 dan RT 07. Jumlah rumah warga di RT 05 berjumlah 120 dan RT 07 berjumlah 150 rumah. Selain ke 2 RT tersebut, penyemprotan juga dilakukan di sepanjang jalan raya/jalan protokol Harjokuncaran, 3 mushola dan 1 masjid Jami', 1 Puskesmas, 1 taman kanak-kanak, 1 sekolah dasar, 2 sekolah menegah pertama, pasar hewan dan balai desa Harjokuncaran seperti yang ditampilkan pada Gambar 1014. Sasaran penyemprotan disinfektan berfokus ke lingkungan warga desa Harjokuncaran dan tempat-tempat umum yang berpotensi sebagai tempat penularan virus Covid-19. 


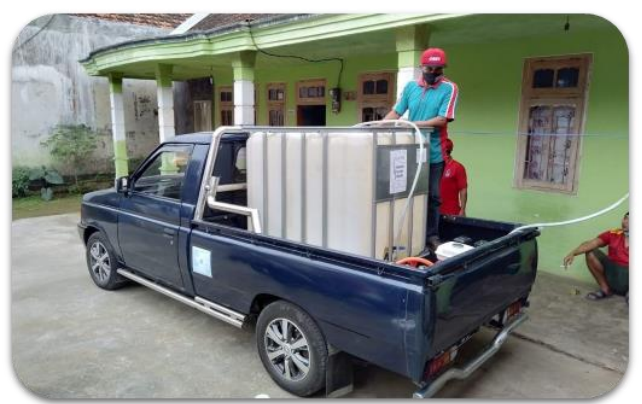

Gambar 10. Proses penataan dan persiapan alat penyemprot disinfektan pada kendaraan pengangkut

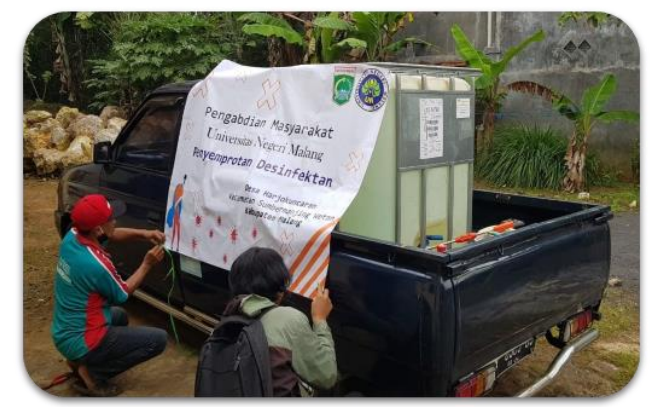

Gambar 11. Pemasangan banner kegiatan pada kendaraan pengangkut alat disinfektan

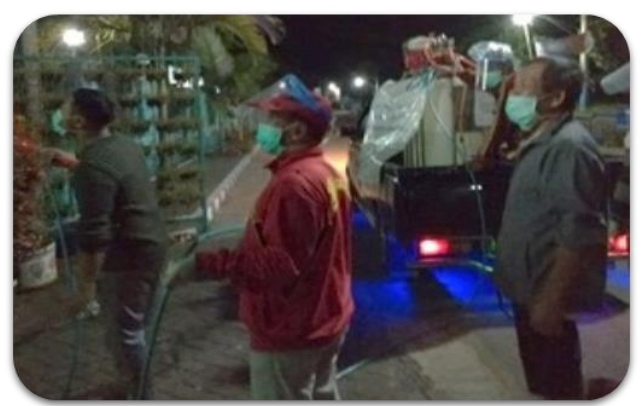

Gambar 12. Pelaksanaan kegiatan penyemprotan di sepanjang jalan protokol Desa Harjokuncaran

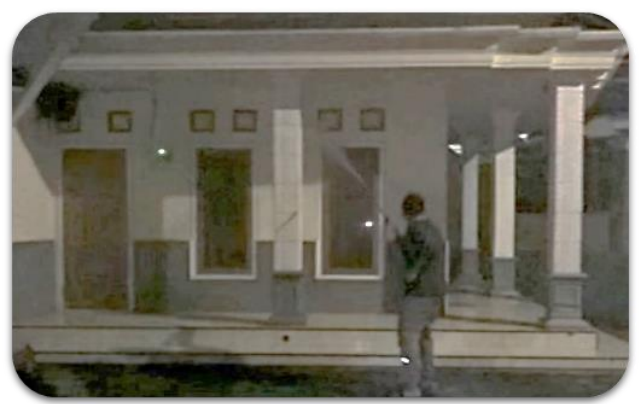

Gambar 13. Pelaksanaan kegiatan sterilisasi pada mushola di Desa Harjokuncaran 


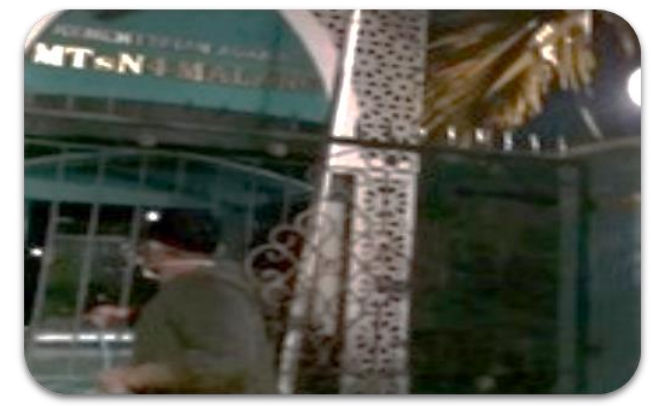

Gambar 14. Pelaksanaan kegiatan sterilisasi di MTsN 4 Malang, Harjokuncaran

\section{Evaluasi (evaluation)}

Setelah implementasi program telah dilaksanakan, maka tahap terakhir yang dilakukan yaitu evaluasi program. Evaluasi program bertujuan untuk menilai program yang telah dilaksanakan apakah berjalan dengan baik. Ada tiga indikator keberhasilan sebagai evaluasi dari kegiatan pengabdian ini yaitu:

a. Kegiatan Awal Penyemprotan Disinfektan

Kegiatan pengabdian ini bertujuan memberi edukasi kepada masyarakat tentang pentingnya penyemprotan disinfektan ke lingkungan sebagai upaya memutus mata rantai penyebaran Covid-19. Kegiatan penyemprotan cairan disinfektan di Desa Harjokuncaran pertama kali dilaksanakan pada tanggal 5 Oktober 2020 seperti ditampilkan pada Gambar 10-14. Warga desa Harjokuncaran antusias mengikuti kegiatan awal penyemprotan dan turut serta dalam kegiatan yang dilakukan pada hari Senin, 5 Oktober 2020 dari sore hari sampai malam hari.

Setelah dilakukanya kegiatan penyemprotan pertama pada tanggal 5 Oktober 2020, kegiatan penyemprotan selanjutnya sepenuhnya diserahkan kepada warga. Rekapan kegiatan penyemprotan yang dilakukan warga pada bulan Oktober 2020 sampai dengan bulan Maret 2021 disajikan dalam Gambar 15. Berdasarkan grafik dari Gambar 9 dapat dilihat pada awal bulan Oktober 2020 penyemprotan menggunakan disinfektan dilakukan sebanyak 8 kali, pada bulan November dilakukan sebanyak 5 kali, pada bulan Desember dilakukan 4 kali, pada bulan Januari kembali dilakukan penyemprotan disinfektan sebanyak 8 kali atau seminggu dilakukan sebanyak dua kali, pada bulan Februari dan Maret dilakukan 7 kali penyemprotan. Dari Gambar 15 dapat disimpulkan bahwa penyemprotan yang dilakukan di Desa Harjokuncaran dilakukan berkisar 4 kali sampai 8 kali dalam satu bulan. 


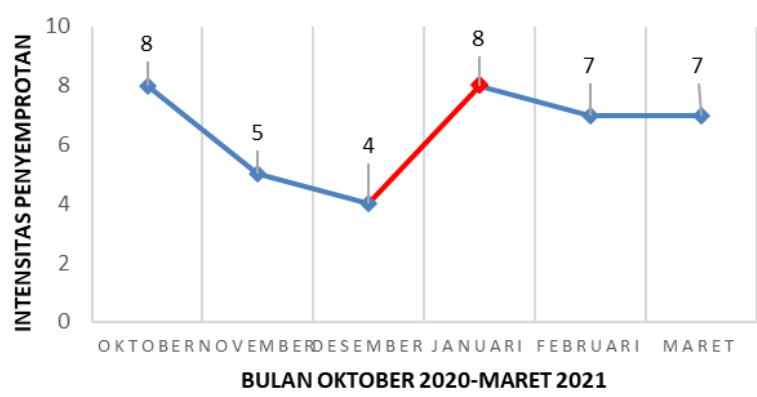

Gambar 15. Grafik frekuensi penyemprotan disinfektan setelah pengadaan alat

b. Pengaruh penyemprotan disinfektan terhadap penambahan kasus positif Covid-19

Untuk kasus penambahan kasus positif di Desa Harjokuncaran ditampilkan pada Gambar 16. Dalam grafik terlihat jumlah positif Covid19, pada bulan Oktober ada 4 kasus, setelah dilakukan penyemprotan rutin sebanyak 8 kali dalam bulan Oktober, terlihat dalam bulan November tidak adanya penambahan jumlah kasus positif Covid-19. Pada bulan November penurunan jumlah penyemprotan disinfektan yang menyebabkan terjadinya penambahan 1 kasus pada bulan Desember dan Januari, tetapi setelah warga kembali melakukan penyemprotan 8 kali pada bulan Januari, terlihat tidak terjadi penambahan kasus pada bulan Februari dan bulan Maret. Hasil ini dapat menjadi alasan bahwa kegiatan penyemprotan disinfektan secara rutin di lingkungan menjadi salah satu kegiatan yang dapat mencegah dan memutus mata rantai penyebaran pandemi Covid-19.

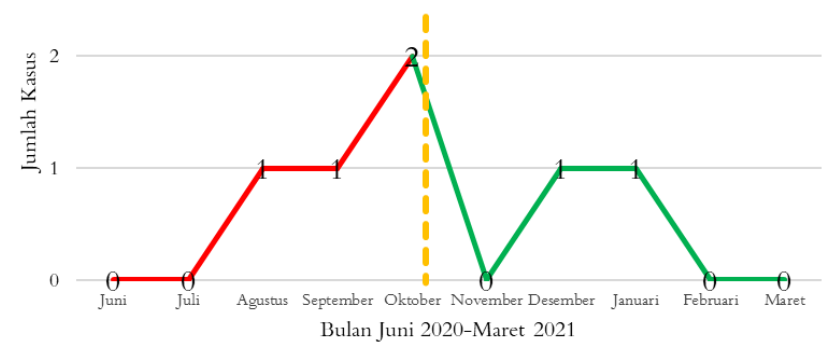

Gambar 16. Grafik Penambahan Kasus Covid-19 di Desa Harjokuncaran Kecamatan Sumbermanjing Wetan Kabupaten Malang

c. Hasil Akhir Kegiatan Pengabdian di Desa Harjokuncaran

Setelah kegiatan awal penyemprotan yang dilakukan pada tanggal 5 Oktober 2020, masyarakat mayoritas sudah memahami pentingnya kegiatan penyemprotan. Hal tersebut didukung dengan data kuesioner per akhir bulan Maret 2021 berdasarkan aktivitas warga selama 6 bulan pasca kegiatan pengabdian. Dari 30 warga desa Harjokuncaran, sebanyak $54 \%$ menyatakan kegiatan penyemprotan disinfektan ini 
sangat penting, $30 \%$ mengatakan penting, $13 \%$ warga menyatakan netral dan hanya $3 \%$ warga menyatakan kegiatan penyemprotan ini kurang penting. Bedasarkan Gambar 17 dapat disimpulkan bahwa $84 \%$ warga memahami pentingnya penyemprotan disinfektan ke lingkungan untuk menurunkan potensi penularan virus Covid-19.

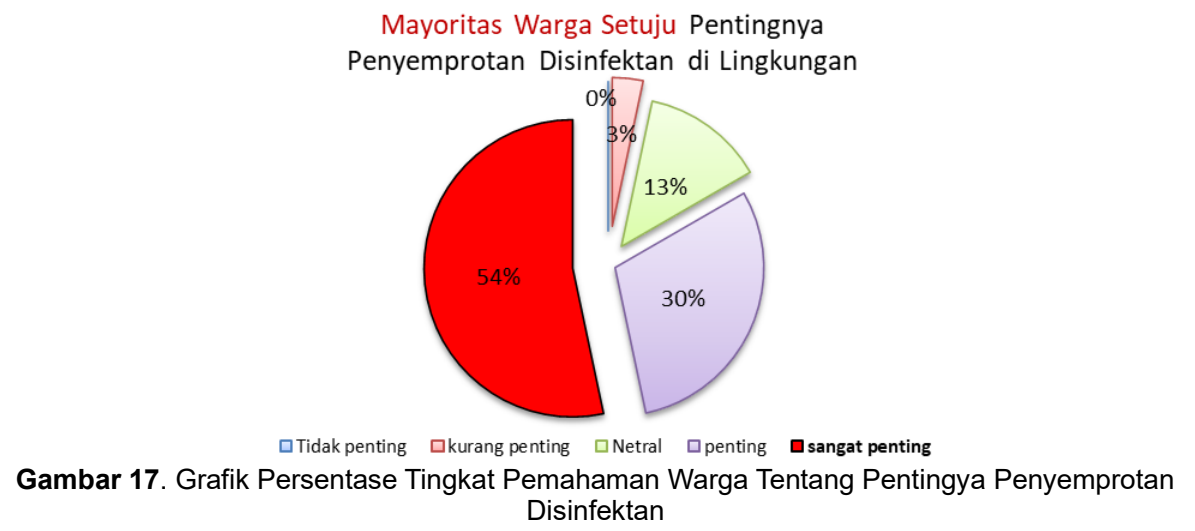

\section{KESIMPULAN}

Kegiatan pengabdian ini berfokus pada pemberian fasilitas sterilisasi dan ajakan untuk melakukan kegiatan disinfeksi secara rutin sebagai upaya untuk memitigasi dan menghindarkan penularan Covid-19 di Desa Harjokuncaran. Kedua alat sterilisasi, baik yang berbahan bakar bensin maupun bertenaga surya, telah diuji dan diserahterimakan kepada warga serta diimplementasikan bersama untuk membersihkan ruang-ruang publik di area desa. Selanjutnya, 6 bulan pasca kegiatan, kegiatan sterilisasi mandiri yang dilakukan oleh warga telah rutin dijadwalkan. Warga Desa Harjokuncaran juga telah menyadari pentingnya kegiatan menjaga kebersihan lingkungan dan berupaya bersama untuk mengurangi tingkat penularan Covid-19. Harapan kami masyarakat Desa Harjokuncaran dapat konsisten dan meningkatkan lagi kesadaran untuk menjaga diri sendiri dengan memenuhi segala protokol kesehatan sebagaimana anjuran dari pemerintah daerah maupun pusat dan meningkatkan intensitas disinfeksi ruang publik dan fasilitas-fasilitas umum dalam masa yang akan datang.

\section{UCAPAN TERIMA KASIH}

Terima kasih kepada LP2M Universitas Negeri Malang yang telah memberikan dukungan penuh terhadap kegiatan ini melalui Anggaran Dana PNBP Tahun Anggaran 2020 Universitas Negeri Malang Nomor 3.3.16/un32/KP/2020 tanggal 3 Maret 2020 melalui Surat Keputusan Rektor Universitas Negeri Malang dalam Pelaksanaan Program Pengabdian Kepada Masyarakat untuk skema Pengabdian Kemitraan Masyarakat (PKM). Terima kasih juga kepada seluruh warga Desa Harjokuncaran yang telah ikut serta dan mendukung program pengabdian ini sehingga dapat berjalan dengan lancar. 


\section{DAFTAR RUJUKAN}

Aboubakr, H. A., Sharafeldin, T. A., \& Goyal, S. M. (2020). Stability of SARSCoV-2 and other coronaviruses in the environment and on common touch surfaces and the influence of climatic conditions: A review. Transboundary and Emerging Diseases, April 2020, 296-312. https://doi.org/10.1111/tbed.13707

Corpet, D. E. (2021). Why does SARS-CoV-2 survive longer on plastic than on paper? Medical Hypotheses, 146, 110429. https://doi.org/10.1016/j.mehy.2020.110429

Dehbandi, R., \& Zazouli, M. A. (2020). Stability of SARS-CoV-2 in different environmental conditions. The Lancet Microbe, 1(4), e145. https://doi.org/10.1016/S2666-5247(20)30093-8

Dignan, M. ., \& Carr, P. . (1992). Program Planning for Health Education and Promotion 2 nd Edition. USA: Lean and Febriger.

Dinkes Kab. Malang. (2021). DATA COVID-19. SATGAS COVID-19 Pemerintah Kabupaten Malang.

Guan, W., Ni, Z., Hu, Y., Liang, W., Ou, C., He, J., Liu, L., Shan, H., Lei, C., Hui, D. S. C., Du, B., Li, L., Zeng, G., Yuen, K.-Y., Chen, R., Tang, C., Wang, T., Chen, P., Xiang, J., ... Zhong, N. (2020). Clinical Characteristics of Coronavirus Disease 2019 in China. New England Journal of Medicine, 382(18), 1708-1720. https://doi.org/10.1056/nejmoa2002032

KPCPEN. (2021). Peta Sebaran COVID-19. Komite Penanganan Covid-19 Dan Pemulihan Ekonomi Nasional (KPCPEN), Satuan Tugas Penanganan COVID-19.

Kwon, T., Gaudreault, N. N., \& Richt, J. A. (2020). Environmental stability of SARS-CoV-2 on different types of surfaces under indoor and seasonal climate conditions.

BioRxiv,

3-9.

https://doi.org/10.1101/2020.08.30.274241

Larasati, A. L., \& Haribowo, C. (2020). Penggunaan Desinfektan dan Antiseptik Pada Pencegahan Penularan Covid-19 di Masyarakat. Majalah Farmasetika, 5(3),

137-145. https://doi.org/10.24198/mfarmasetika.v5i3.27066

Li, W., Zhang, B., Lu, J., Liu, S., Chang, Z., Peng, C., Liu, X., Zhang, P., Ling, Y., Tao, K., \& Chen, J. (2020). Characteristics of Household Transmission of COVID-19. Clinical Infectious Diseases, 71(8), 19431946. https://doi.org/10.1093/cid/ciaa450

Morawska, L., Tang, J. W., Bahnfleth, W., Bluyssen, P. M., Boerstra, A., Buonanno, G., Cao, J., Dancer, S., Floto, A., Franchimon, F., Haworth, C., Hogeling, J., Isaxon, C., Jimenez, J. L., Kurnitski, J., Li, Y., Loomans, M., Marks, G., Marr, L. C., ... Yao, M. (2020). How can airborne transmission of COVID-19 indoors be minimised? Environment International, 142(May). https://doi.org/10.1016/j.envint.2020.105832

Musafira, Fardinah, Qardini, L., Fatimah, M. F., Ardiputra, S., \& Asrirawan. (2020). Edukasi pembuatan dan penyemprotan desinfektan pada masyarakat di desa suruang kecamatan campalagian kabupaten polewali mandar. Communnity Development Journal, 1(3), 416-421. 
Nugrahaeni, F., \& Permanasari, E. D. (2021). Edukasi Perilaku Hidup Bersih Sehat dan Pembagian Masker, Handsanitizer kepada Warga Jatisari. Abdimasku: Jurnal Pengabdian Masyarakat, 4(1), 1. https://doi.org/10.33633/ja.v4i1.162

Nur, M. A. N., \& Baru, S. (2021). Penyemprotan Desinfektan Di Musholla an Nur, Kelurahan Sawah Baru, Ciputat, Tangerang Selatan. 2, 101-106.

Olivia, S., Gibson, J., \& Nasrudin, R. (2020). Indonesia in the Time of Covid-19. Bulletin of Indonesian Economic Studies, 56(2), 143-174. https://doi.org/10.1080/00074918.2020.1798581

Peretto, G., Sala, S., \& Caforio, A. L. P. (2020). Acute myocardial injury, MINOCA, or myocarditis? Improving characterization of coronavirusassociated myocardial involvement. European Heart Journal, 41(22), 2124-2125. https://doi.org/10.1093/eurheartj/ehaa396

Phillipson, J., Gorton, M., Turner, R., Shucksmith, M., Aitken-McDermott, K., Areal, F., Cowie, P., Hubbard, C., Maioli, S., McAreavey, R., SouzaMonteiro, D., Newbery, R., Panzone, L., Rowe, F., \& Shortall, S. (2020). The COVID-19 pandemic and its implications for rural economies. Sustainability (Switzerland), $12(10), \quad 1-9$. https://doi.org/10.3390/SU12103973

Ranscombe, P. (2020). Rural areas at risk during COVID-19 pandemic. The Lancet. Infectious Diseases, 20(5), 545. https://doi.org/10.1016/S14733099(20)30301-7

Shim, E., Tariq, A., Choi, W., Lee, Y., \& Chowell, G. (2020). Transmission potential and severity of COVID-19 in South Korea. International Journal of Infectious Diseases, 93, 339-344. https://doi.org/10.1016/j.ijid.2020.03.031

Sohrabi, C., Alsafi, Z., O'Neill, N., Khan, M., Kerwan, A., Al-Jabir, A., Iosifidis, C., \& Agha, R. (2020). World Health Organization declares global emergency: A review of the 2019 novel coronavirus (COVID-19). International Journal of Surgery, 76(February), 71-76. https://doi.org/10.1016/j.ijsu.2020.02.034

Suryahadi, A., Al Izzati, R., \& Suryadarma, D. (2020). Estimating the Impact of Covid-19 on Poverty in Indonesia*. Bulletin of Indonesian Economic Studies, 1-34. https://doi.org/10.1080/00074918.2020.1779390

van Doremalen, N., Trenton, B., Morris, D. H., Holbrook, M. G., Gamble, A., Williamson, B. N., Tamin, A., Harcourt, J. L., Thornburg, N. J., Gerber, S. I., Lloyd-Smith, J. O., de Wit, E., \& Munster, V. J. (2020). Aerosol and Surface Stability of SARS-CoV-2 as Compared with SARS-CoV-1. New England Journal of Medicine, 1-3. https://doi.org/10.1056/NEJMc2004973

WHO. (2020). Pembersihan dan disinfeksi permukaan lingkungan dalam konteks COVID-19. In Panduan interim. 